\title{
Communication
}

[Comunicação]

\section{Osteopetrosis and osteonecrosis in snake Boa constrictor}

[Osteopetrose e osteocondrose em serpente Boa constrictor]

N.M. Ocarino, C.E. Goulart, S.M. Falci, P.C. Souza, R. Serakides*

Escola de Veterinária - UFMG

Caixa Postal 567

30123-970 - Belo Horizonte, MG

\begin{abstract}
Osteopetrosis and osteonecrosis are generalized metabolic diseases. Osteopetrosis is characterized by the increase of bone mass (Seifert et al., 1993; Rozin et al., 2005) due to the increased bone synthesis or reduction of bone absorption. Osteonecrosis is characterized by osteocyte death and bone matrix decomposition (Krook et al., 1971). In domestic animals, the most frequent causes of osteopetrosis and osteonecrosis are intoxications with vitamin D, corticoids, and hypercalcitoninism (Krook et al., 1971; Santos et al., 1976; Krook, 1983). In humans, the main cause of osteopetrosis is gene mutation (Filho et al., 2005). Today, an increasingly common cause of osteopetrosis and osteonecrosis in humans is bisphosphanateinduced osteonecrosis of the jaw, commonly seen in patients being treated for osteoporosis (Marx et al., 2005), although the etiology is considered complex and poorly understood. A survey of the literature has not found any report of osteopetrosis and osteonecrosis in snakes, either captive or in the wild. Osteopenic diseases, such as rickets and osteomalacia, are the most frequent reported for reptiles, and occur due to inappropriated diet (Reece et al., 1986). In snakes, osteitis due to Salmonella infection has been reported in a captive colony (Ramsay et al., 2002). The purpose of the present work was to report osteopetrosis and osteonecrosis in Boa constrictor, a large boid snake.
\end{abstract}

Recebido em 25 de janeiro de 2007

Aceito em 30 de julho de 2008

*Autor para correspondência (corresponding author)

E-mail: serakide@dedalus.lcc.ufmg.br

Apoio: FAPEMIG e CAPES (Edital pro-equipamentos 01/2007)
A male boa (Boa constrictor) about $1.60 \mathrm{~m}$ total length, was referred to a veterinary hospital. The snake had been held in captivity for 11 years with the permission of the Instituto Brasileiro do Meio Ambiente (IBAMA), and lived indoors under a controlled temperature environment, feeding on mice and hamsters twice a month. The owner reported that enlargements along the spine had been noticed about six months earlier, followed by progressive decreases in movement and feeding.

A painful response to physical examination was noted. Radiological examination of the whole animal revealed an increase in opacity of the cranial and medium third of the vertebral column with areas of bone enlargement and several fractures (Fig. 1A and 1B).

Due to a poor prognosis, the snake was euthanased. At necropsy, bony excrescences with vertebral canal stenosis and spinal cord compression were observed along spine dorsal portion. Several complete and incomplete fractures of vertebral bodies were present (Fig. $2 \mathrm{~A}$ and $2 \mathrm{~B}$ ). With the exception of changes in the locomotor system, the other organs were apparently normal. Tissue samples were collected from selected organs (heart, lung, kidney, liver, and brain) and throughout the spinal cord (normal and abnormal areas). Bones were decalcified and all tissues were embedded in paraffin, sectioned and stained with haematoxylin and eosin. 


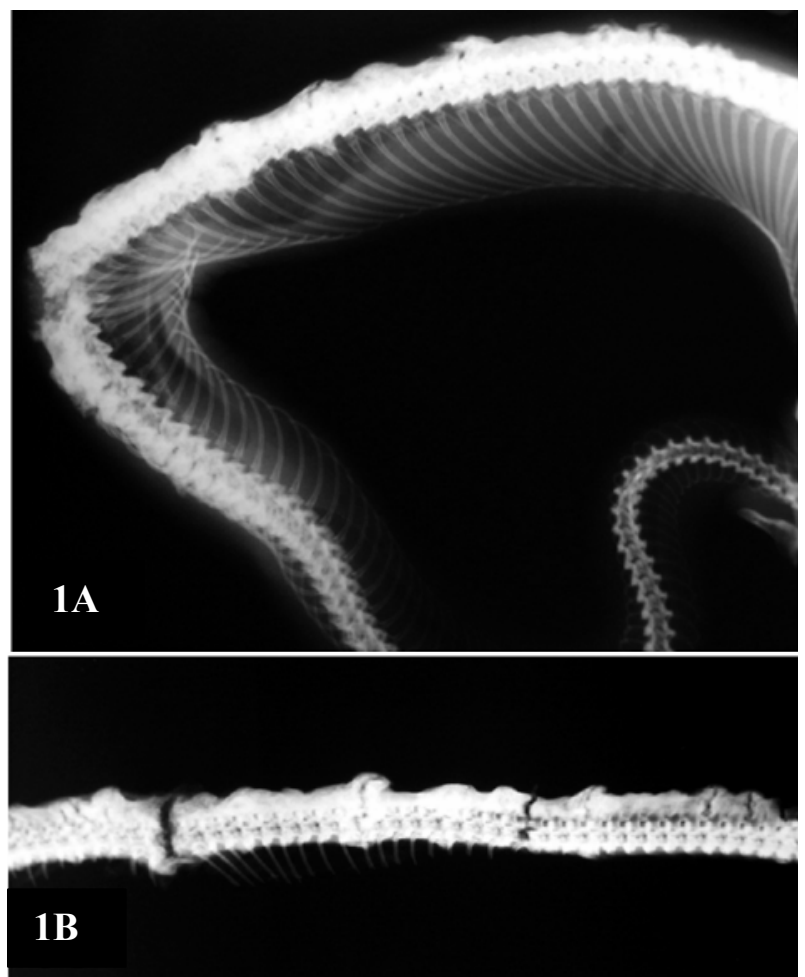

Figure 1. Radiograph of the vertebral column of a Boa constrictor snake with osteopetrosis and osteonecrosis. A) Ventrodorsal radiograph of the vertebral column. Increase in opacity of the cranial and medium third of the vertebral column. B) Sagittal plane. Areas of bone exuberances and several complete and incomplete fractures of vertebral bodies.
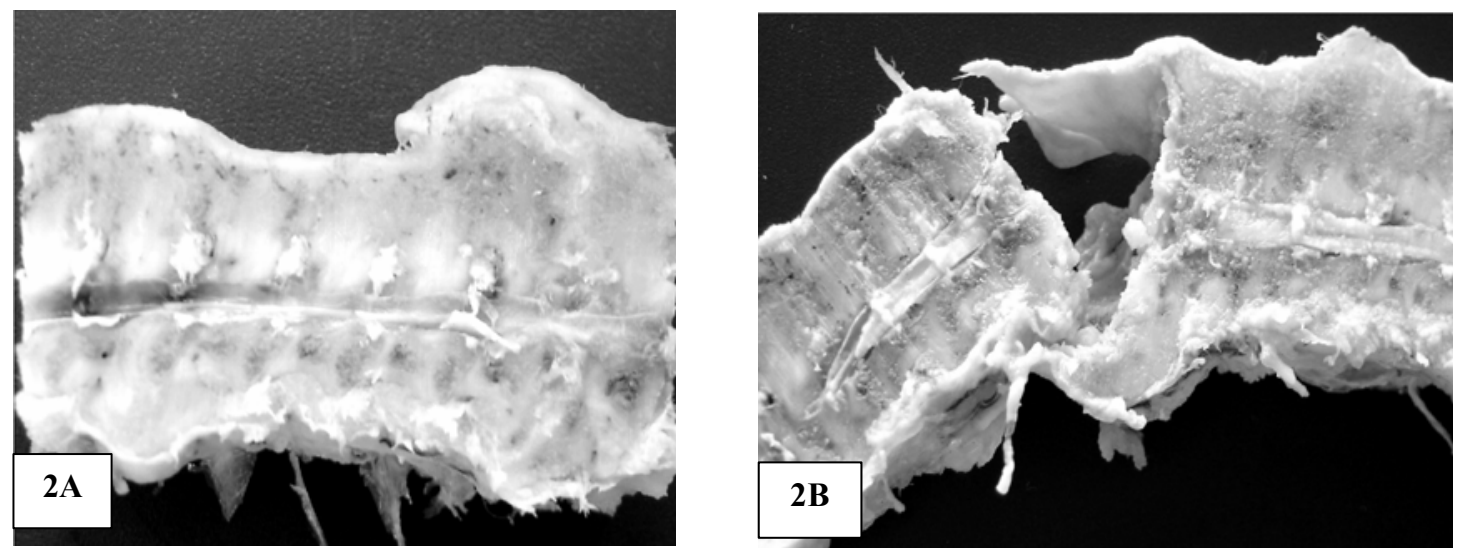

Figure 2. Osteopetrosis and osteonecrosis in a Boa constrictor snake. A) Bony excrescences with vertebral canal stenosis and spinal cord compression. B) Complete fracture of vertebral body.

An increase of bone quantity, both cortical and trabecular bone, was histologically observed. Trabeculae were confluent and thick with formation of osteons (Fig. 3A). Sometimes, it was impossible to distinguish between trabecular and compact bone. Numerous cement lines produced mosaic patterns indicative of retarded osteocytic osteolysis. Many bone sections had large numbers of empty osteocyte lacunae (Fig. 3B). At fractures sites, there was a disintegration of bone matrix (Fig. 3C) and moderate areas of fibroplasia and proliferation of normal cartilaginous tissue, representing attempt to repair. No osteoclasts were observed. Tissue 

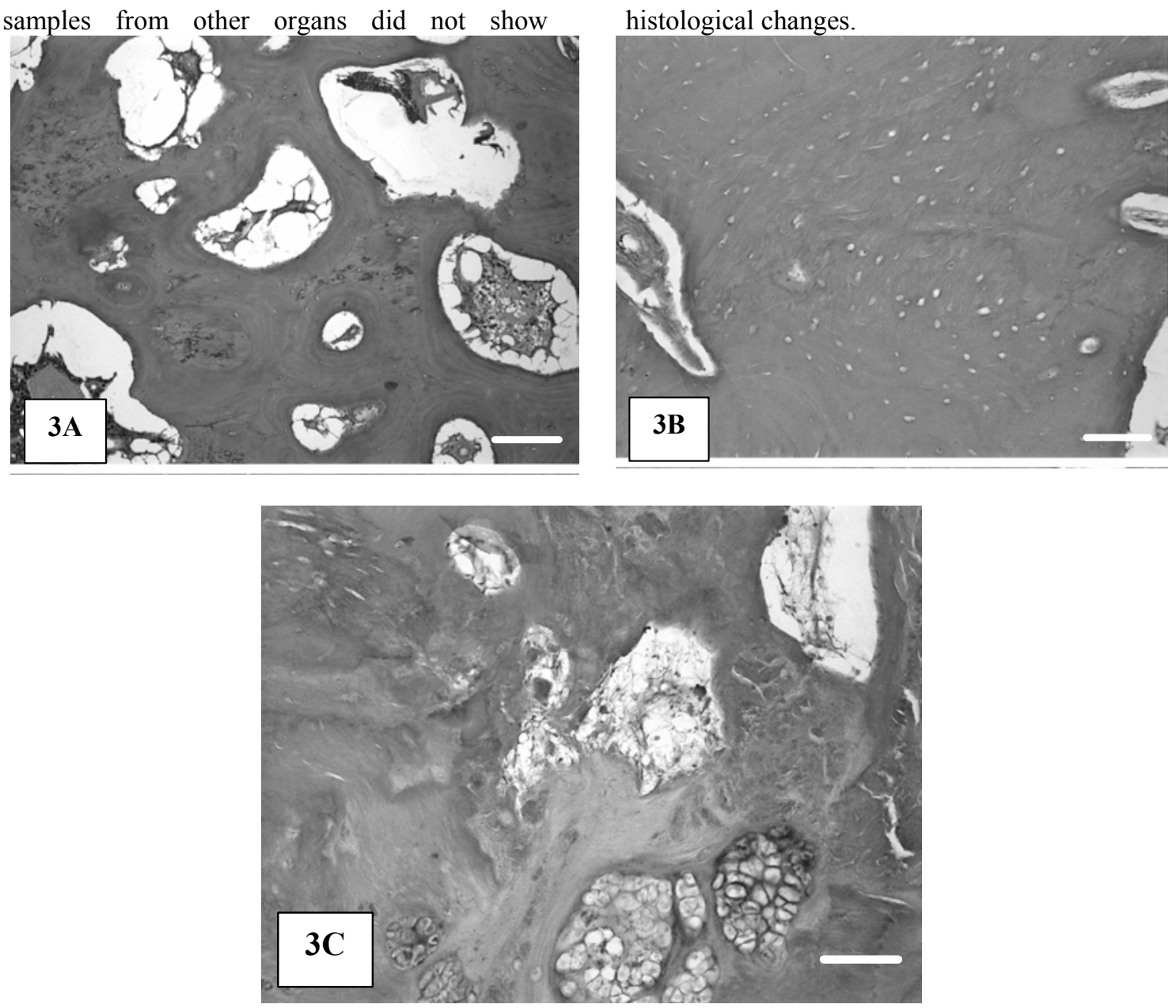

Figure 3. Osteopetrosis and osteonecrosis in a Boa constrictor snake. A) Marked increase in the amount of compact bone, characterized by narrowing of the Haversian canals and increased number of cement lines giving a mosaic appearance to the tissue. HE, bar $=93 \mu \mathrm{m}$. B) Several pycnotic osteocytes within enlarged lacunae, and large numbers of empty osteocytic lacunae. HE, bar=93 $\mu \mathrm{m}$. C) Multifocal disintegration of the bone matrix. $\mathrm{HE}$, bar $=47 \mu \mathrm{m}$.

Based on gross and histopathological findings, a diagnosis of osteopetrosis and osteonecrosis was confirmed. After radiological examination, differential diagnosis included Paget disease and bone neoplasia, but both were excuded by histopathological findings. Paget disease in $\mathrm{Boa}$ constrictor has been reported (Frye and Carney, 1974), but this disorder is characterized by excessive local or multifocal bone production (Roodman and Windle, 2005; Rozin et al., 2005); in contrast to the more generalized osteopetrosis in the present case. Further, in Paget disease, the most important histological change is the increase of number and size of osteoclasts (Roodman and Windle, 2005), which was not seen in the present case.

Although it was not possible to determine the cause of the osteopetrosis and osteonecrosis, nutritional disorders such as overfeeding or hypervitaminosis appear unlikely as the snake diet was in accordance with typical recommendations.

Keywords: snake, Boa constrictor, osteopetrosis, osteonecrosis 


\section{RESUMO}

Uma jibóia (Boa constrictor), de onze anos de cativeiro, apresentou à seis meses um histórico de aumento de volume ao longo da coluna vertebral e perda progressiva dos movimentos e de apetite. Exames radiológicos revelaram aumento da opacidade, áreas de excrescências ósseas e inúmeras fraturas ao longo da coluna. Devido o prognóstico desfavorável, a serpente foi eutanasiada. À necropsia, aumento de volume com estenose do canal vertebral e compressão da medula espinhal foram observados, juntamente com fraturas completas de corpos vertebrais. O diagnóstico de osteopetrose e osteonecrose foi firmado à histologia.

Palavras-chave: serpente, Boa constrictor; osteopetrose, osteonecrose

\section{REFERENCES}

FILHO, A.M.; DOMINGOS, A.C.; FREITAS, D.Q. et al. Osteopetrosis - a review and report of two cases. Oral Dis., v.11, p.46-49, 2005.

FRYE, F.L.; CARNEY, J. Osteitis deformans (Paget's Disease) in Boa Constrictor. Vet. Med. Small Anim. Clin., v. 69, p.186-188, 1974.

KROOK, L.; LUTWAK, L.; MCENTEE, K. et al. Nutritional hypercalcitoninism in bulls. Cornell. Vet., v.61, p.625-639, 1971.

KROOK, L. Metabolic disease of bone and bones. New York: Cornell University, 1983. 54p.

MARX, R.E.; SAWATARI, Y.; FORTIN, M. et al. Bisphosphonate-Induced exposed bone (ostepetrosis/osteonecrosis) of the jaws: risk factors, recognation, prevention, and treatment. J. Oral. Maxillofac. Surg., v.63, p.1567-1575, 2005.

RAMSAY, E.C.; DANIEL, G.B.; TRYON, B.W. et al. Osteomyelitis associated with Salmonella enterica SS arizonae in a colony of ridgenose rattlesnakes (Crotalus willardi). J. Zoo Wildl. Med., v.33, p.301-10, 2002.

REECE, R.L.; DICKSON, D.B.; BUTLER, R. An osteopetrosis-like condition in a juvenile rhinocerus iguana (Cyclura cornuta). Aust. Vet. J., v.63, p.343-344, 1986.

ROODMAN, G.D.; WINDLE, J. Paget disease of bone. J. Clin. Invest., v.115, p.200-208, 2005.

ROZIN, A.; BAR-SHALOM, R.; ISHSHALOM. Paget's disease of bone or osteopetrosis? Clin. Rheumatol., v.19, p.1-4, 2005.

SANTOS, M.N.; NUNES, V.A.; NUNES, I.J. et al. Solanum Malacoxylon toxicity: inhibiton of bone resorption. Cornell Vet., v.66, p.565-588, 1976.

SEIFERT, M.F.; POPOFF, S.N.; JACKSON, M.E. et al. Experimental studies of osteopetrosis in laboratory animals. Clin. Orthop. Rel. Res., v.94, p.23-33, 1993. 